\title{
Relations Among Sorghum Ergot Isolates from the Americas, Africa, India, and Australia
}

Sylvie Pažoutová, Institute of Microbiology Czech Academy of Sciences, Laboratory of the Physiology and Genetics of Filamentous Fungi, Videnska 1083, 14220 Prague 4, Czech Republic; Ranajit Bandyopadhyay, Genetic Resources and Enhancement Program, International Crops Research Institute for the Semi-Arid Tropics, Patancheru, Andhra Pradesh 502 324, India; Debra E. Frederickson, Matopos Research Station, P/Bag K5137, Bulawayo, Zimbabwe; Peter G. Mantle, Imperial College of Science, Technology and Medicine, Department of Biochemistry, London, SW7 2AY, UK; and Richard A. Frederiksen, Department of Plant Pathology and Microbiology, 120 L. F. Peterson Building, Texas A\&M University, College Station 77843

\begin{abstract}
Pažoutová, S., Bandyopadhyay, R., Frederickson, D. E., Mantle, P. G., and Frederiksen, R. A. 2000. Relations among sorghum ergot isolates from the Americas, Africa, India, and Australia. Plant Dis. 84:437-442.

Sorghum ergot, initially restricted to Asia and Africa, was recently found in the Americas and Australia. Three species causing the disease have been reported: Claviceps sorghi in India, $C$. sorghicola in Japan, and C. africana in all ergot-positive countries. The objective of our study was to study the intraspecific variation in $C$. africana isolates in the Americas, Africa, India, and Australia. We confirmed C. africana, C. sorghi, and C. sorghicola as different species using differences in nucleotide sequences of internal transcribed spacer 1 and 5.8S rDNA regions. Sequences of this region obtained from the representative American, Indian, and Australian isolates of $C$. africana were identical. In addition, random amplified polymorphic DNA (RAPD) banding patterns of sorghum ergot pathogen isolates from the United States, Mexico, Puerto Rico, Bolivia, Australia, and India were evaluated with nearly 100 primers. A total of 65 primers gave identical patterns for all isolates, which confirmed that all were C. africana. The identity of RAPD pattern and rDNA sequence of Indian isolates with those of $C$. africana confirmed that the species is now present in India. Only 20 primers gave small pattern differences and 7 of them were used for routine testing. All of the American isolates were identical and three isolates of the same type were also found in South Africa, suggesting Africa as the origin of the invasion clone in the Americas. Australian and Indian isolates were distinguishable by a single band difference; therefore, migration from the Asian region to Australia is suspected. Another distinct group was found in Africa. Cluster analysis of the informative bands revealed that the American and African group are on the same moderately (69\%) supported clade. Isolates from Australia and India belonged to another clade.
\end{abstract}

Additional keywords: Sphacelia sorghi, sugary disease

Ergot disease of sorghum recently gained prominence due to sudden expansion in its geographical distribution (5). The disease is a serious constraint in the production of $F_{1}$ hybrid seed, an essential input in productive sorghum cultivation systems worldwide. Crop losses are caused by reducing the quantity and quality of seed, seed predisposition to seedling diseases, and difficult harvesting and threshing. The presence of ergot bodies in seed

Corresponding author: R. A. Frederiksen E-mail: r-frederiksen@tamu.edu

This work was supported by the International Sorghum/Millet Collaborative Research Program (INTSORMIL) and also, in part, by grant 206/97/0611 of the Czech Grant Agency.

Accepted for publication 13 December 1999.

Publication no. D-2000-0207-01R

(C) 2000 The American Phytopathological Society creates serious problems in the international trade of sorghum produce.

Sorghum ergot was first detected in India in 1917 (24) and, subsequently, in Kenya in 1923 from its co-occurrence with the specific hyperparasite Cerebella andropogonis Cesati which overgrows sphacelia (23). The ergot pathogen colonizes ovaries, replacing them individually with the sphacelial mass. Sphacelia (anamorphic conidiogenous form of Claviceps spp.) exude sweet, sticky honeydew in which millions of conidia are released. Later, the fungal tissues may differentiate to form sclerotia. Initial research on sorghum ergot, conducted in Samaru, Nigeria in the mid-1960s by a team of researchers from the Agricultural Research Service of the United States Department of Agriculture, illustrated the high susceptibility of male-sterile parents of $F_{1}$ hybrids (16).

Three Claviceps spp. have been reported to cause ergot in different parts of the world. These are C. sorghi Kulkarni, Seshadri, and Hegde, $C$. africana Frederickson, Mantle, and de Milliano, and $C$. sorghicola Tsukiboshi, Shimanuki, and Uematsu. C. sorghi was first reported as the perfect stage in India in 1976 (20), and for the next 15 years was also assumed to represent the perfect stage of the sorghum pathogen in Africa. C. africana was formally described as the cause of sorghum ergot in Zimbabwe in 1991 (12), and $C$. sorghicola in Japan in 1999 (33).

C. africana, C. sorghi, and C. sorghicola are distinguished as different species by their teleomorph morphology (features of stipe, capitulum, asci, and ascospores), morphology of sclerotia (small and rounded in $C$. africana, elongated and protruding in $C$. sorghi), dihydroergosine content of sclerotia in $C$. africana, and ability to produce secondary conidia $(11,12,20,33)$. The imperfect stages of $C$. sorghi and $C$. africana are similar and are both named Sphacelia sorghi McRae (24). Conidia of $C$. sorghicola are much smaller in size than those of the other two species.

The global distribution of sorghum ergot has been recently summarized (5). Introduction of $F_{1}$ hybrid seed technology is linked to the enhanced importance and wider distribution of ergot in Africa and Asia $(3,8,11)$. After being restricted to Asia and Africa for nearly 80 years, sorghum ergot was detected in Brazil in mid-1995 and identified as $C$. africana (26). C. africana spreads most efficiently by windborne secondary conidia $(11,13)$ and, by mid-1996, the disease was reported from Argentina, Paraguay, Uruguay, and Bolivia, countries close to ergot-affected areas in Brazil. Subsequently, the disease continued to spread northeastwards, covering Colombia, Venezuela, and Honduras by the end of 1996, and the Caribbean, Mexico (35), and the continental United States by the end of March 1997 (17). C. africana was reported from Australia in April 1996. The source country of inoculum introduction into the Americas and Australia is not clearly known. However, an African country was initially assumed to be the source of inoculum introduced into Brazil and Australia because $C$. africana was known 
as prevalent only in Africa before ergot spread to the Americas. Recent alkaloid analyses revealing the presence of dihydroergosine in the Indian isolates proved that $C$. africana is present in India, too (7).

In India, smaller sclerotia resembling the ones of $C$. africana frequently occurred naturally in the field together with the elongated sclerotia typical only for of $C$. sorghi $(4,28)$. However, the second author has not seen typical sclerotia of $C$. sorghi naturally occurring in the field during the last 12 years. The ergot pathogen in India also produces secondary conidia (6), a character associated with $C$. africana and not $C$. sorghi (12). Therefore, the need to determine the identity and distribution of the ergot pathogen in India was stated earlier (14).

Sclerotia of $C$. africana do not germinate readily (12). Therefore, traditional methods of identifying Claviceps spp. using teleomorph characters are impractical. DNA-based methods are good molecular tools to resolve problems of identification of plant pathogens (19) as demonstrated in several pathogens including species of Mycosphaerella causing Sigatoka disease of banana and plantain (18).

The objective of our research was to study the intraspecific variability of the $C$. africana isolates recently collected in the United States, Mexico, Puerto Rico, Bolivia, India, South Africa, and Australia with respect to the possible origin of invasion clones in the Americas and Australia. An authenticated isolate each of $C$. sorghi from India and C. sorghicola from Japan were also included in the study for comparison. We used random amplified polymorphic DNA (RAPD) and sequencing of internal transcribed spacer (ITS) 1 and 5.8S rDNA regions to substitute for traditional mycological methods of germinating sclerotia of sorghum-infecting Claviceps spp. for pathogen characterization.

\section{MATERIAL AND METHODS}

A total of 28 isolates of $C$. africana from the United States, Mexico, Puerto Rico, Bolivia, Australia, India, and South Africa (Table 1) were used in the RAPD study. Isolates from the United States, Mexico, Puerto Rico, and Bolivia are together termed "American" isolates in this paper. The DNA from $C$. sorghicola (Japan), $C$. sorghi (India), and one representative ergot isolate each from Bolivia, Australia, and India were used in the nucleotide sequence work. DNA of $C$. sorghi and C. sorghicola was isolated from sclerotia. Sclerotia of $C$. sorghi were formed in England in 1987 on male sterile sorghum line 2219A inoculated by an isolate originating from Akola, Maharashtra, and India (identical to that described in 12). Sclerotia of C. sorghicola were similarly derived in England in 1996 from male-sterile sorghum inoculated with conidia of the pathogen provided by $\mathrm{T}$. Tsukiboshi.

Isolation and cultivation of the mycelial cultures. Indian isolates were isolated from infected panicles collected at different locations and sent to the International Crops Research Institute for the Semi-Arid Tropics (ICRISAT). Panicles were soaked

Table 1. Identity of Claviceps africana isolates, their origin (location), year of collection, and collector's name

\begin{tabular}{|c|c|c|c|}
\hline Isolate $^{\mathrm{a}}$ & Origin & Collected & Source \\
\hline Dharwar 2 & Dharwar, Karnataka, India & 1997 & S. Indira \\
\hline ICRISAT 2 & Patancheru, Andhra Pradesh, India & 1997 & R. Bandyopadhyay \\
\hline Unknown & India $^{b}$ & 1997 & S. Indira \\
\hline Akola 2 & Akola, Maharashtra, India & 1997 & C. Sangitrao \\
\hline Indore & Indore, Madhya Pradesh, India & 1997 & S. Indira \\
\hline Australia & Mutchilba, Queensland, Australia & 1996 & J. L. Alcorn \\
\hline T10 763 & Norwin, Queensland, Australia & 1996 & M. J. Ryley \\
\hline T10 764 & Norwin, Queensland, Australia & 1996 & M. J. Ryley \\
\hline T10 765 & Mutdapilly, Queensland, Australia & 1996 & M. J. Ryley \\
\hline T10 777 & Kingaroy, Queensland, Australia & 1997 & M. J. Ryley \\
\hline Bolivia 2 & Bolivia $^{\mathrm{b}}$ & 1996 & P. G. Mantle \\
\hline Е 627 & Kelly Green, Texas & 1997 & R. A. Frederiksen \\
\hline A $623 / 1^{\mathrm{c}}$ & College Station, Texas & 1997 & R. A. Frederiksen \\
\hline A $623 / 2^{c}$ & College Station, Texas & 1997 & R. A. Frederiksen \\
\hline A $357 / 1^{\text {c }}$ & Texas A\&M Research Farm, College Station, Texas & 1997 & R. A. Frederiksen \\
\hline TAMU & Texas A\&M Research Farm, College Station, Texas & 1997 & R. A. Frederiksen \\
\hline MX 2.1 & Celaya, Mexico & 1998 & R. Bandyopadhyay \\
\hline MX 2.2 & Celaya, Mexico & 1998 & R. Bandyopadhyay \\
\hline MX 6 & Celaya, Mexico & 1998 & R. Bandyopadhyay \\
\hline MX 8 & Celaya, Mexico & 1998 & R. Bandyopadhyay \\
\hline MX 9.2 & Celaya, Mexico & 1998 & R. Bandyopadhyay \\
\hline PR CI & Puerto Rico & 1998 & R. Bandyopadhyay \\
\hline Africa 1 & Potchefstroom, Northwest, South Africa & 1998 & N. W. McLaren \\
\hline Africa $2 / 1$ & Hazyview, Mpumalanga, South Africa & 1999 & N. W. McLaren \\
\hline Africa $2 / 2$ & Hazyview, Mpumalanga, South Africa & 1999 & N. W. McLaren \\
\hline Africa $3 / 3$ & Hazyview, Mpumalanga, South Africa & 1999 & N. W. McLaren \\
\hline
\end{tabular}

${ }^{a}$ Host of all isolates is Sorghum bicolor, except T10 764 which was isolated from Sorghum spp.

b Place of collection is unknown.

c Isolated from greenhouse-grown infected plants. in water to release ergot conidia from the honeydew. Male-sterile sorghum panicles in the greenhouse were immersed in the resultant conidial suspension and bagged to induce infection on fresh stigmas. Young (5 days after inoculation) sphacelia were dissected from infected flowers before honeydew exudation, surface sterilized in $1 \%$ sodium hypochlorite for $3 \mathrm{~min}$, rinsed five times in sterile water, and plated on potato dextrose agar (PDA) medium. Passage of the fungus through the plant ensured a higher success rate for obtaining pure cultures than isolation from the fieldcollected samples that were often heavily contaminated with saprophytes.

Australian isolates were obtained as pure cultures authenticated as $C$. africana. The American and African isolates were cultivated directly from infected plant material. Young sclerotia or sphacelia were surfacesterilized for $15 \mathrm{~min}$ in $1.3 \%$ sodium hypochlorite, washed for 1 to $2 \mathrm{~min}$ in $95 \%$ $\mathrm{EtOH}$, and rinsed three times in distilled water. Sterilized sclerotia were placed on T2 agar plates (30) supplemented with 100 $\mu \mathrm{g} / \mathrm{ml}$ of ampicillin. T2 medium (per liter of distilled $\mathrm{H}_{2} \mathrm{O}$ ) is composed of sucrose, $100 \mathrm{~g}$; L-asparagine, $10 \mathrm{~g}$; yeast extract, $0.1 \mathrm{~g} ; \mathrm{KH}_{2} \mathrm{PO}_{4}, 0.25 \mathrm{~g} ; \mathrm{MgSO}_{4} \cdot 7 \mathrm{H}_{2} \mathrm{O}, 0.25$ g; $\mathrm{FeSO}_{4} \cdot 7 \mathrm{H}_{2} \mathrm{O}, 0.02 \mathrm{~g} ; \mathrm{ZnSO}_{4} \cdot 7 \mathrm{H}_{2} \mathrm{O}$, $0.015 \mathrm{~g} ; \mathrm{KCl}, 0.12 \mathrm{~g} ; \mathrm{Ca}\left(\mathrm{NO}_{3}\right)_{2} \cdot 4 \mathrm{H}_{2} \mathrm{O}, 1 \mathrm{~g}$; agar, $20 \mathrm{~g}$; $\mathrm{pH}$ 5.2. The isolates were maintained on T2 or PDA agar slants at $4^{\circ} \mathrm{C}$ and subcultured every 3 to 6 months.

Preparation of genomic DNA. Spore or mycelium suspensions of the isolates were plated on cellophane discs laid on $\mathrm{T} 2$ or PDA plates and grown for 2 to 3 weeks at $24^{\circ} \mathrm{C}$. Mycelium was scraped to liquid nitrogen and ground to a fine powder. To $0.5 \mathrm{~g}$ of mycelium, $3 \mathrm{ml}$ of extraction buffer (2\% Triton X-100; $1 \%$ sodium dodecyl sulfate; $0.25 \mathrm{M} \mathrm{NaCl} ; 0.1 \mathrm{M}$ Tris$\mathrm{HCl}, \mathrm{pH} 7.8$; 0.1 M EDTA, $\mathrm{pH}$ 8.2) and 3 $\mathrm{ml}$ of phenol-chloroform were added. The suspension was gently agitated for $15 \mathrm{~min}$, centrifuged at $10,000 \times g$, and the supernatant precipitated for $2 \mathrm{~h}$ with 0.7 volume of isopropanol at $0^{\circ} \mathrm{C}$. The pellet was dissolved in $3 \mathrm{ml}$ of $1 \times$ Tris-EDTA, pH 8.2, treated with $50 \mu \mathrm{g}$ of RNAse, extracted two to three times with chloroform, precipitated with 0.7 volume of isopropanol/0.3M sodium acetate, and dissolved in 200 to $300 \mu \mathrm{l}$ of sterile $\mathrm{H}_{2} \mathrm{O}$. Polysaccharides were then partially removed by the addition of $150 \mu \mathrm{l}$ of Nucleon PhytoPure DNA extraction resin (Amersham Life Science, Amersham, UK) and $400 \mu \mathrm{l}$ of chloroform cooled to $-20^{\circ} \mathrm{C}$, shaken for $10 \mathrm{~min}$ at room temperature, and centrifuged at $10000 \times g$ for $10 \mathrm{~min}$. The DNA was precipitated from the water phase with 0.7 volume of isopropanol/0.3M sodium acetate.

DNA from C. sorghi was isolated from $0.3 \mathrm{~g}$ of sclerotia by the above method without Nucleon treatment. The purified DNA was degraded to a smear, but amena- 
ble to polymerase chain reaction (PCR) amplification. DNA from $C$. sorghicola was isolated from two sclerotia ground in liquid nitrogen and processed as above in 1:10 scale, again without Nucleon treatment. The sample DNA was only slightly degraded.

DNA sequencing. The region containing ITS1 and part of the 5.8S rDNA was amplified using primers ITS1 and ITS2 (36). The mixture $(25 \mu \mathrm{l})$ contained $50 \mathrm{ng}$ of genomic DNA, 20 pmol of each primer, $0.2 \mathrm{mM}$ dNTPs (Promega Corp., Madison, WI), and $1 \mathrm{U}$ of DynaZyme with the respective buffer (Finnzymes, Oy, Finland). The reaction mixtures were subjected to 32 cycles in a GeneE thermal cycler (Techne, Cambridge, UK) under the following temperature regime: $95^{\circ} \mathrm{C} / 3 \mathrm{~min}, 55^{\circ} \mathrm{C} / 30 \mathrm{~s}$, $72^{\circ} \mathrm{C} / 1 \mathrm{~min}(1$ time $), 95^{\circ} \mathrm{C} / 30 \mathrm{~s}, 55^{\circ} \mathrm{C} / 30 \mathrm{~s}$, $72^{\circ} \mathrm{C} / 1 \mathrm{~min}$ (30 times), and $95^{\circ} \mathrm{C} / 30 \mathrm{~s}$, $55^{\circ} \mathrm{C} / 30 \mathrm{~s}, 72^{\circ} \mathrm{C} / 10 \mathrm{~min}$ (1 time) with hot start. Amplified fragments were purified by the Wizard DNA Clean-Up System (Promega Corp.) and subjected to an automatic AmpliTaq polymerase cycle sequencing process using the same primers with dye terminator labeling. Sequences were read on an ABI 373A sequencer (Perkin-Elmer Corp., Norwalk, CT) at the sequencing facility in the Institute of Biotechnology TU, Graz, Austria. The sequences were deposited in the EMBL Nucleotide Sequence Database under the accession numbers AJ011590 (C. africana Bolivia 2), AJ011783 (Australian isolate T 10 765), AJ011784 (Indian isolate), AJ011591 (C. sorghicola), and AJ242869 (C. sorghi). Sequences were aligned by ClustalX (32).

RAPD analyses. The reaction mixture contained in $20 \mu \mathrm{l}: 0.2 \mathrm{mM}$ dNTPs, 20 pmol of the primer, Dynazyme reaction buffer, Dynazyme polymerase $1 \mathrm{U}$, and $\mathrm{MgCl}_{2}$ in a total concentration of $1.75 \mathrm{mM}$ (unless otherwise stated). DNA (50 ng) was added and the samples were placed on the cycler plate after its temperature reached $80^{\circ} \mathrm{C}$. The cycling was as follows: $94^{\circ} \mathrm{C} / 3 \mathrm{~min}, 38^{\circ} \mathrm{C} / 1 \mathrm{~min}, 72^{\circ} \mathrm{C} / 20 \mathrm{~s}(1$ time); $93^{\circ} \mathrm{C} / 20 \mathrm{~s}, 38^{\circ} \mathrm{C} / 1 \mathrm{~min}, 72^{\circ} \mathrm{C} / 20 \mathrm{~s}$ (33 times); $93^{\circ} \mathrm{C} / 20 \mathrm{~s}, 38^{\circ} \mathrm{C} / 1 \mathrm{~min}, 72^{\circ} \mathrm{C} / 6$ min (1 time). The resulting bands were separated on 1 or $2 \%$ agarose gel (SeaKem LE agarose, FMC BioProducts, ME) in $1 \times$ Tris-borate-EDTA at $4 \mathrm{~V} \mathrm{~cm}^{-1}$ for 2 to $4 \mathrm{~h}$ (21). The primers that gave pattern differences on a subset of five isolates were tested twice on the complete isolate set for reproducibility and optimized for $\mathrm{MgCl}_{2}$ concentration. Only the bands that appeared in all experiments were scored. A total of 10 variable positions obtained with seven primers (Table 2) were pooled. Analysis was done using the software Treecon for Windows 1.3b (34). A distance matrix was calculated using simple matching coefficient (31) and a dendrogram was constructed using unweighted pair-group method with arithmetic mean
(UPGMA) by algorithms contained in it. Bootstrap analysis was performed using 500 bootstrapped values (10).

\section{RESULTS}

The nucleotide sequences of the region containing ITS1 and part of the 5.8S rDNA determined in $C$. africana isolates from Bolivia, Australia, and India were identical (Fig. 1) and different from either C. sorghi or C. sorghicola. These results corroborate the validity of recognizing three different species colonizing sorghum.

The RAPD patterns of 28 isolates (Table 1) of C. africana were evaluated with over 100 primers from an unrelated sequencing project (14 to 20 mers) and from decamer kits OPA and OPE purchased from Operon
Technologies, Inc. (Alameda, CA). Of these primers, 65 produced uniform species-specific patterns for all isolates, which further proved that they belong to the same species. Seven primers (Table 2) discriminated between four groups: (i) all American isolates and three African isolates, (ii) two African isolates, (iii) Indian, and (iv) Australian isolates (Fig. 2). Australian isolates were distinguished from the Indian group with the primer ITP5, where acquisition of a single band was observed. No other polymorphic bands (shared by at least two isolates) that would discriminate inside these groups were found.

Computer analysis of 10 variable bands (Fig. 3) gave an UPGMA tree where African isolates (Africa 1 and Africa 2/2)

Table 2. Random amplified polymorphic DNA primers used for differentiating Claviceps africana isolates from the Americas, Africa, India, and Australia

\begin{tabular}{llc}
\hline Primer & \multicolumn{1}{c}{ Sequence $\left(\mathbf{5}^{\prime}\right.$ to $\left.\mathbf{3}^{\prime}\right)$} & Optimum $\mathbf{M g C l}_{\mathbf{2}} \mathbf{( \mathbf { m M } )}$ \\
\hline OPA01 & CAGGCCCTTC & 1.75 \\
OPA09 & GGGTAACGCC & 1.75 \\
8F & GCTCTGAGATTGTTCCGGCT & 1.75 \\
5R & TTTGTCCGGCTCAGAAAC & 1.75 \\
10R & GGCCAGTGTGAATATGC & 2.75 \\
30F & GAGGACGATTCATCAACC & 1.5 \\
ITP5 & CCGGCTTGTATTGG & 1.75 \\
\hline
\end{tabular}

Bolivia

T10 765

India

C. sorghi

Bolivia

T10 765

India

C. sorghicola

C. sorghi

Bolivia

T10 765

India

C. sorghicola

C. sorghi

Bolivia

T10 765

India

C. sorghicola

C. sorghi

Bolivia

T10 765

India

c. sorghicola

C. sorghi
C. sorghicola

ATCATTACCGAGTTTACAACTCCCAAACCCCATGTGAACCTCTACCGAAACGTTGCCTC ATCATTACCGAGTTTACAACTCCCAAACCCCCATGTGAACCTCTACCGAAACGTTGCCTC ATCATTACCGAGTTTACAACTCCCAAACCCCCATGTGAACCTCTACCGAAACGTTGCCTC ATCATTACCGAGTTTACA-CTCCCAAACCCCC-TGTGAACCTCTACCGAA-CGTTGCCTC ATCATTACCGAGTTTACA-CTCCCAAACCCCCATGTGAACCTCTACCGAA-CGTTGCCTC

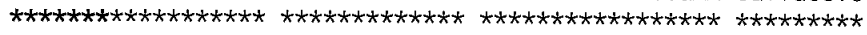

GGCGGGA - TGCGT - - - - CCCGGCCCGCCCCTCTGGGGTGCCGGAACCAAGGCGGCCCGC GGCGGGA-TGCGT - - - - CCCGGCCCGCCCCTCTGGGGTGCCGGAACCAAGGCGGCCCGC GGCGGGA-TGCGT - . - - CCCGGCCCGCCCCTCTGGGGTGCCGGAACCAAGGCGGCCCGC GGCGGG - - GGCGC - - GGACGCGCGCCGTCCC - - - - - - - - - - - CCCCCGC GGCGGGAACGCGCCCCGGCCCGCCCCCCCCCAC-GGGCGCCGGGAACCAGGACCGACCGC

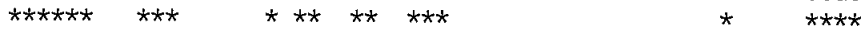

CGGGGGACCCCAACCAGAA - - CTCTGTAA - - - - CACCTCCGGGAACGTCTGAGTGGAT CGGGGGACCCCAACCAGAA - - CTCTGTAA - . - - CACCTCCGGGAACGTCTGAGTGGAT CGGGGGACCCCAACCAGAA - - CTCTGTAA - . - - CACCTCCGGGAACGTCTGAGTGGAT CGGGGGACCCAAACCAAAAA-CTCTTGTATCCTCCCA--TCGTGGCATGTCTGAGTGGAT CGGGGGA- - - AACCAGAAACCCTCTGTATC- T-CCA- - . - - GGAACGTCTGAGTGGAT $* * * * * * * \quad * * * * * * * \quad * * * * \quad * * \quad * * * * * * * * * * * * * * *$

TTA-- CCAAATGAATCAAAACTTTCAACAACGGATCTCTTGGTTCTGGCATCGATGAAG TTA-- -CCAAATGAATCAAAACTTTCAACAACGGATCTCTTGGTTCTGGCATCGATGAAG TTA-- -CCAAATGAATCAAAACTTTCAACAACGGATCTCTTGGTTCTGGCATCGATGAAG TTA - - TCAAATGAATCAAAACTITCAACAACGGATCTCTAGGTTCTGGCATCGATGAAG TTAGTATCAAATGAATCAAAACTTTCAACAACGGATCTCTTGGCTCTGGCATCGATGAAG

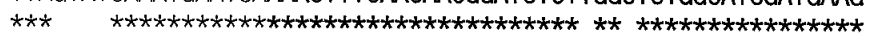

Fig. 1. Alignment of internal transcribed spacer (ITS) 1 to 5.8S rDNA sequences from Claviceps sorghi, C. sorghicola, and three isolates of C. africana from Bolivia, Australia (T10 765) and India. The $3^{\prime}$ terminal nucleotides of $18 \mathrm{~S}$ rDNA and the $5^{\prime}$ part of 5.8S rDNA are in bold. A star $\left(^{*}\right)$ indicates the identity between the nucleotide sequences of the species. 
formed moderately supported (69\%) clade with groups consisting of American isolates, Africa 2/1, Africa 2/3, and Africa $3 / 3$. The second clade was formed by Indian and Australian isolates.

\section{DISCUSSION}

We expected that the Indian isolates may be different from the American and Australian isolates because only C. sorghi had been reported in India so far. However, three representative isolates from Bolivia, Australia, and India had identical nucleotide sequences in the ITS1 and part of the
5.8S rDNA regions. The Australian isolates had been confirmed as $C$. africana (27) after comparison with the type $C$. africana isolate from Zimbabwe (12). Our conclusion that $C$. africana is present in India is further supported by similarity in the RAPD patterns. The same conclusion was also recently arrived at by Bogo and Mantle (7) using biological and biochemical data.

C. sorghi was undoubtedly present in India, but the presence of $C$. africana went undetected earlier. A comparative study of C. africana and C. sorghi (12) used only

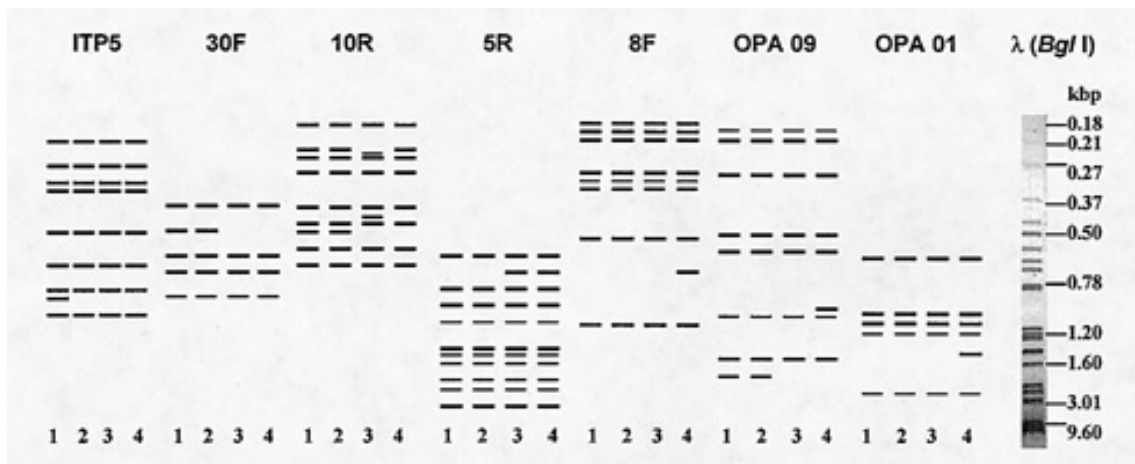

Fig. 2. Schematic random amplified polymorphic DNA patterns of the groups and isolates of Claviceps africana. 1 = Australian isolates; $2=$ Indian isolates; $3=$ African isolates Africa 1 and Africa $2 / 2$; and $4=$ American isolates and African isolates Africa2/1, 2/3, and 3/3. Only the reproducible bands, regardless of their intensity, were scored. No other bands that would discriminate inside the groups were found.

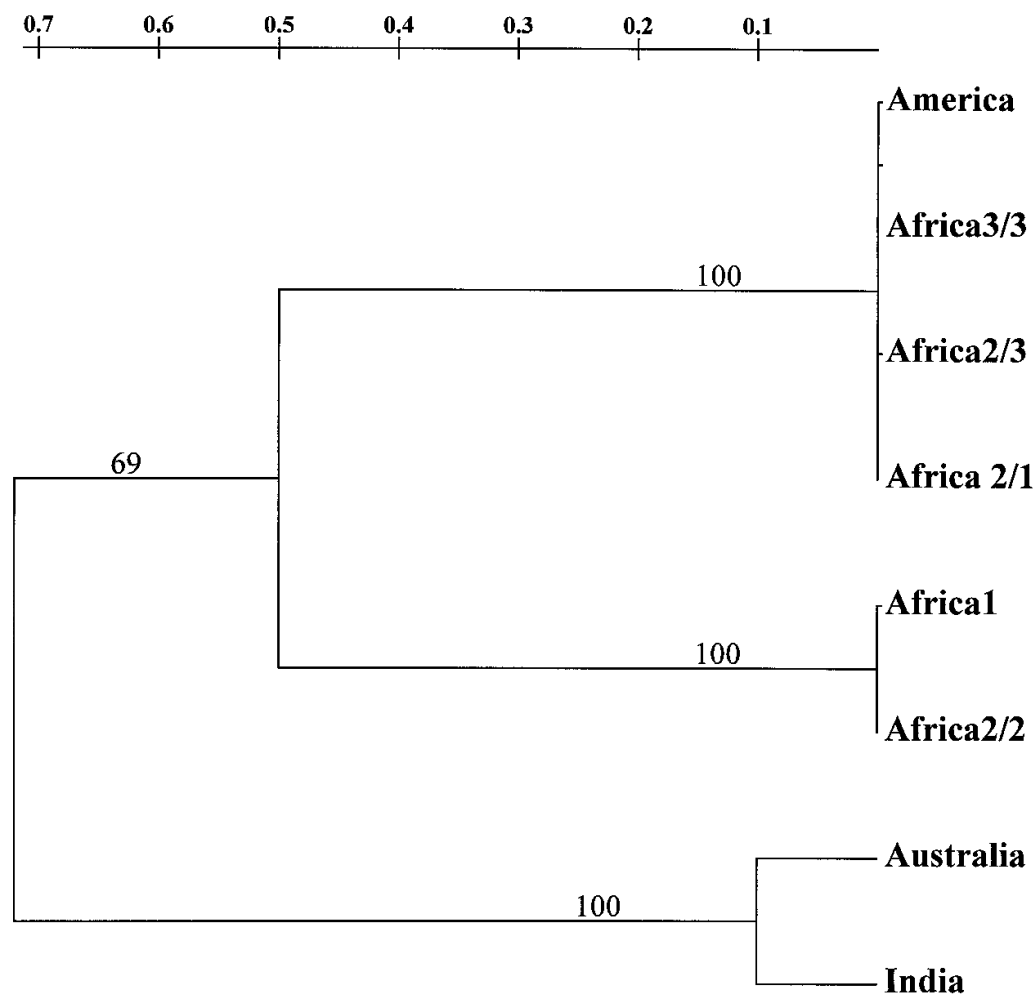

Fig. 3. Dendrogram constructed from random amplified polymorphic DNA data showing the relatedness of Claviceps africana groups. Matrix of pairwise distances was calculated using simple matching coefficient (distances shown above the dendrogram). The dendrogram was generated using unweighted pair group method with arithmetic mean. Bootstrap values are given on appropriate branches.

the large sclerotia of C. sorghi from Akola, India, which germinated readily. However, problems with sclerotial germination in $C$. africana were highlighted and it was the main factor delaying the proper description of $C$. africana. All attempts to germinate the smaller sclerotia of size and shape similar to $C$. africana have been futile in India.

A literature search and its interpretation in the present context suggest that there may have been a gradual change in the species causing sorghum ergot in India to the possible predominance of $C$. africana over $C$. sorghi at present. Sclerotia of different sizes have been seen in India. Early Indian observations during 1914 to 1917 (1) and 1946 (25) on ergot in Karnataka and Andhra Pradesh States, as well as a survey in Akola (Maharashtra state) and Dharwar (Karnataka state) during the early 1960s (29), mention mostly large elongated sclerotia found on sorghum. Both long and short sclerotia were observed in the late 1970s $(20,28)$ to mid-1980s (Fig. 3), which might have been due to variability in the size of sclerotia of $C$. sorghi or to a start of C. africana infections. In any case, since the late 1980s, the typical long and protruding sclerotia of $C$. sorghi have not been observed in the fields in Karnataka, Andhra Pradesh, and Maharashtra states (Fig. 4). However, an analysis of population structure with more isolates from each location is necessary to determine the relative preponderance of the two sorghum ergot species in India.

The RAPD patterns of a limited number of recent isolates from Akola and Dharwar, where only $C$. sorghi had been reported earlier $(12,20)$, show that there has been a change in the species composition of sorghum ergot in India. There may not be a way to precisely document when the changes began. We hypothesize that the process started with the introduction of hybrid seed technology in India in the 1970s.

Reproductive potential is an important determining factor for the relative predominance of two pathogen species competing for the same niche in an ecosystem. Production of secondary conidia and their spontaneous wind dispersal are most likely the key characters of pathogenic fitness in sorghum ergot. The ability of $C$. africana to rapidly produce wind-dispersible secondary conidia (11) offers the pathogen a remarkable potential to spread quickly over time and space (13). Also, environmental conditions (high humidity, dew, or rain) favorable for the production of secondary conidia occur frequently, allowing the continual presence of secondary conidia in the air for a long period. In contrast, $C$. sorghi does not produce secondary conidia in vivo (12). The absence of secondary conidia in C. sorghi makes it rely primarily on rain splash for spread. Rain-splash dispersal is periodic because it is dependent on rain 
events that are not frequent in the semi-arid tropics where sorghum is grown. Therefore, C. africana has greater potential for spread, making it epidemiologically more fit than C. sorghi. After the appearance of C. africana in India, greater dispersal efficiency and potential to spread are most likely the major factors related to its predominance over C. sorghi. In retrospect, the isolate used in the study that demonstrated the production of secondary conidia in C. sorghi (6) most probably belonged to $C$. africana, because the production of secondary conidia is a typical feature of this species and morphology of the conidiation was identical to the species described in Zimbabwe $(11,12)$.

The ITS-rDNA sequence of the three species causing sorghum ergot differed substantially, confirming species differentiation determined on morphological characters. Both C. africana and C. sorghicola are present in Japan $(22,33)$ and $C$. sorghicola does not produce secondary conidia in nature; therefore, it would be interesting to study the changes in the population structures of the two sorghum ergots in Japan over a period of time.

Partitioning of the $28 C$. africana isolates into four geographically distinct groups suggests that pathogen introduction into the Americas and Australia may have occurred from two different sources. India, or a Southeast Asian country such as Thailand, where $C$. africana is also present (12), is the likely origin of ergot introduction into Australia. Similarities in the RAPD pattern of isolates from India and Australia support this assumption. On the other hand, the presence of isolates with identical patterns in South Africa and in the Americas suggests that Africa is the source of ergot pathogen introduction in the Americas.

There is little likelihood of the occurrence of sexual recombination as a mechanism to generate variability in $C$. africana because sclerotia germinate inefficiently in vitro and germination has not been reported in nature. Moreover, C. purpurea was found to be homothallic (9); therefore, the same mechanism could apply for $C$. africana. The lack of a sexual cycle combined with homothallism will no doubt lead to a clonal character for $C$. africana populations. Also, repeated recovery of uniform patterns in the isolates over several years and long distances suggests predominant clonal reproduction (2), at least inside the rapidly invading populations. There is a need to analyze the population variability of $C$. africana isolates from across Africa to elucidate the spreading patterns and population structure of $C$. africana. Our preliminary result with isolates from just two localities have shown

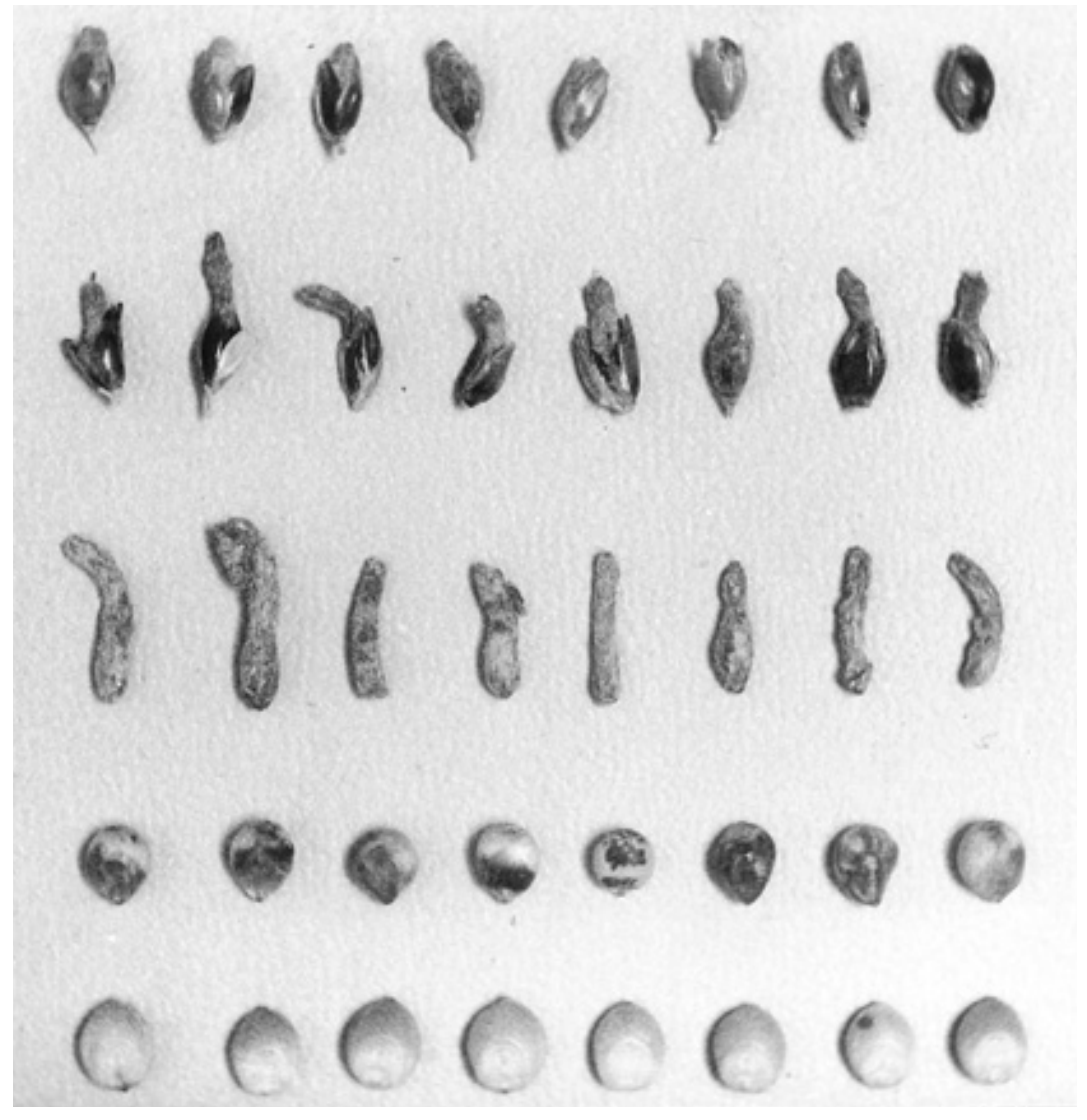

Fig. 4. Differences in the size of sorghum ergot sclerotia and grain discoloration because of honeydew. Top to bottom: small sclerotia concealed inside glumes, long sclerotia with glumes, long sclerotia removed from glumes, discolored seed, and healthy seed. Sclerotia were collected in 1985 from the same sorghum field in Akola, Maharashtra State, India. that representatives of different groups occurred in the same field, which may suggest greater variability.

Intensive research on late blight of potato and tomato has shown that maximum diversity in Phytophthora infestans occurs in the highlands of Mexico (15). Taking into account the spreading pattern of $C$. africana in Africa during the past 40 years, we suggest that the highlands of eastern Africa, a region close to the center of origin of sorghum and where ergot continues to be endemic, is the most likely geographic area for the center of diversity for C. africana. Analysis of isolates from this region could give clues to the origin of the aggressive clones that have begun to threaten sorghum worldwide during the past 10 years.

\section{ACKNOWLEDGMENTS}

We thank P. Vízner for excellent technical assistance; M. Ryley, S. Indira, and N. McLaren for providing the sorghum ergot isolates; and $\mathrm{C}$. Magill and B. Fry for useful comments on an initial draft of the manuscript.

\section{LITERATURE CITED}

1. Ajrekar, S. L. 1926. Observations on a disease of Jowar (Sorghum vulgare) caused by Sphacelia (conidial stage of Claviceps). J. Indian Bot. Soc. 2:55-61.

2. Anderson, J. B., and Kohn, L. M. 1995. Clonality in soilborne plant-pathogenic fungi. Annu. Rev. Phytopathol. 33:369-391.

3. Bandyopadhyay, R. 1992. Sorghum ergot Pages 235-244 in: Sorghum and Millets Diseases: A Second World Review. W. A. J. de Milliano, R. A. Frederiksen, and G. D. Bengston eds. International Crops Research Institute for the Semi-Arid Tropics, Patancheru, India.

4. Bandyopadhyay, R., Frederickson, D. E., McLaren, N. W., and Odvody, G. N. 1996. Ergot-a global threat to sorghum. Int. Sorghum Millet Newsl. 37:1-32.

5. Bandyopadhyay, R., Frederickson, D. E., McLaren, N. W., Odvody, G. N., and Ryley, M. J. 1998. Ergot: a new disease threat to sorghum in the Americas and Australia. Plant Dis. 82:356-367.

6. Bandyopadhyay, R., Mughogho, L. K., Manohar, S. K., and Satyanarayana, M. V. 1990. Stroma development, honeydew formation, and conidial production in Claviceps sorghi. Phytopathology 80:812-818.

7. Bogo, A., and Mantle, P. G. 1999. Claviceps africana discovered in India. Plant Dis. 83:79.

8. de Milliano, W. A. J., Tavares Nogueira, M. F. R., Pomela, L. M., Msiska, F. S., Kunene, S., Matalaote, B., Mbwaga, A. M., Kaula, G. M. and Mtisi, E. 1991. New records of ergot of sorghum caused by Sphacelia sorghi in southern Africa. Plant Dis. 75:215.

9. Esser, K., and Tudzynski, P. 1978. Proof of a monoecious life cycle and segregation patterns for mycelial morphology and alkaloid production. Theor. Appl. Genet. 53:145-150.

10. Felsenstein, J. 1985. Confidence limits on phylogenies: an approach using the bootstrap. Evolution 39:783-791.

11. Frederickson, D. E., Mantle, P. G., and de Milliano, W. A. J. 1989. Secondary conidiation of Sphacelia sorghi on sorghum, a novel factor in the epidemiology of ergot disease. Mycol. Res. 93:497-502.

12. Frederickson, D. E., Mantle, P. G., and de Milliano, W. A. J. 1991. Claviceps africana sp. nov., the distinctive ergot pathogen of sorghum in Africa. Mycol. Res. 95:1101-1107. 
13. Frederickson, D. E., Mantle, P. G., and de Milliano, W. A. J. 1993. Windborne spread of ergot disease (Claviceps africana) in sorghum A-lines in Zimbabwe. Plant Pathol. 42:368377.

14. Frederiksen, R. A., Thomas, M. D., Bandyopadhyay, R., and Mughogho, L. K. 1995. Variable pathogens of sorghum. Pages 11-23 in: Disease Analysis Through Genetics and Biotechnology. Interdisciplinary Bridges to Improved Sorghum and Millet Crops. J. F. Leslie and R. A. Frederiksen, eds. Iowa State University Press, Ames.

15. Fry, W. E., and Goodwin, S. B. 1997. Reemergence of potato and tomato blight in the United States. Plant Dis. 81:1349-1357.

16. Futrell, M. C., and Webster, O. J. 1966. Host range and epidemiology of the sorghum ergot organism. Plant Dis. Rep. 50:828-831.

17. Isakeit, T., Odvody, G. N., and Shelby, R. A. 1998. First report of sorghum ergot in the United States. Plant Dis. 82:592.

18. Johanson, A., and Jeger, M. 1993. Use of PCR for detection of Mycosphaerella fijiensis and M. musicola, the causal agents of Sigatoka leaf spots of banana and plantain. Mycol. Res. 67:670-674.

19. Kohn, L. M. 1992. Developing new characters for fungal systematics: an experimental approach for determining the rank of resolution. Mycologia 84:139-153.

20. Kulkarni, B. G. P., Seshadri, V. S., and Hegde, R. K. 1976 The perfect stage of Sphacelia sorghi McRae. Mysore J. Agric. Sci. 10:286289.
21. Maniatis, T., Fritsch, E F., and Sambrook, J. 1982. Molecular Cloning. A Laboratory Manual. Cold Spring Harbor Laboratory Press, Cold Spring Harbor, New York.

22. Mantle, P. G., and Hassan, H. A. G. 1994. Widening geographical distribution of Claviceps africana, an important ovary pathogen of grain sorghum. Int. Sorghum Millet Newsl. 35:97-98.

23. McDonald J. 1923. Report of the mycologist. Pages 81-85 in: Annu. Rep. Kenya Dep. Agric., Nairobi, Kenya.

24. McRae, W. 1917. Notes on some south Indian fungi. Madras Agric. Yearb. 1917:108-111.

25. Ramakrishnan, T. S. 1948. Ergot sclerotia on Sorghum vulgare Pers. Curr. Sci. 17:218.

26. Reis, E. M., Mantle, P. G., and Hassan, H. A. G. 1996. First report in the Americas of sorghum ergot disease, caused by a pathogen diagnosed as Claviceps africana. Plant Dis. 80:463.

27. Ryley, M. J., Alcorn, J. L., Kochman, J. K., Kong, G. A., and Thompson, S. M. 1996. Ergot on Sorghum spp. in Australia. Aust. Plant Pathol. 25:214.

28. Sangitrao, C. S., and Bade, G. H. 1979. Morphological studies of sclerotia of sorghum ergot. Sorghum Newsl. 22:108.

29. Singh, P. 1964. Sugary disease of sorghum. Pages 29-33 in: Progr. Rep. Accelerated Hybrid Sorghum Proj. Millet Improve. Programme. Indian Counc. Agric. Res., New Delhi, India.

30. Spalla, C. 1973. Genetic problems of production of ergot alkaloids in saprophytic and parasitic conditions, Pages 393-403 in: Genetics of Industrial Microorganisms. Z. Vanek, Z. Hošálek, and J. Cudlín, eds. Elsevier, Amsterdam.

31. Sneath, P. H. A., and Sokal, R. R. 1973. Numerical Taxonomy. W. H. Freeman, San Francisco.

32. Thompson, J. D., Gibson, T. J., Plewniak, F., Jeanmougin, F., and Higgins, D. G. 1997. The ClustalX windows interface: flexible strategies for multiple sequence alignment aided by quality analysis tools. Nucleic Acids Res. 24:4876-4882.

33. Tsukiboshi, T., Shimanuki T., and Uematsu, T. Claviceps sorghicola sp. nov., a destructive ergot pathogen of sorghum in Japan. Mycol. Res. In press.

34. van de Peer, Y., and De Wachter, R. 1997. Construction of evolutionary distance trees with TREECON for Windows: accounting for variation in nucleotide substitution rate among sites. Comput. Appl. Biosci. 13:227 230 .

35. Velasquez-Valle, Narro-Sanchez, J., MoraNoasca, R., and Odvody, G. N. 1998. Spread of ergot (Claviceps africana) in Central Mexico. Plant Dis. 82:447.

36. White, T. J., Bruns, T., Lee, S., and Taylor, J. W. 1990. Amplification and direct sequencing of fungal ribosomal RNA genes for phylogenetics. Pages 315-322 in: PCR Protocols: A Guide to Methods and Applications. M. A. Innis, D. H. Gelfand, J. J. Sninsky, and T. J. White, eds. Academic Press, San Diego, CA. 